\title{
Pedicled and skeletonized single and bilateral internal thoracic artery grafts and the incidence of sternal wound complications: Insights from the Arterial Revascularization Trial
}

\author{
Umberto Benedetto, MD, PhD, ${ }^{a}$ Douglas G. Altman, DSc, ${ }^{b}$ Stephen Gerry, MSc, ${ }^{b}$ Alastair Gray, PhD, ${ }^{c}$ \\ Belinda Lees, BSc, PhD, ${ }^{\mathrm{d}}$ Rafal Pawlaczyk, PhD, ${ }^{\mathrm{e}}$ Marcus Flather, MD, ${ }^{\mathrm{f}}$ and David P. Taggart, MD, PhD, \\ on behalf of the Arterial Revascularization Trial investigators
}

\begin{abstract}
Objectives: The question of whether skeletonized internal thoracic artery harvesting reduces the incidence of sternal wound complications in comparison with the pedicled technique, in the context of single or bilateral internal thoracic arteries, remains controversial. We studied the impact of the internal thoracic artery harvesting strategy on sternal wound complication in the Arterial Revascularization Trial.

Methods: Patients enrolled in the Arterial Revascularization Trial $(n=3102)$ were randomized to coronary artery bypass grafting with single or bilateral internal thoracic arteries. Sternal wound complication rates were examined according to the harvesting technique that was documented in 2056 patients. The internal thoracic artery harvesting technique, based on the surgeon's preference, resulted in 4 groups: pedicled single internal thoracic artery $(n=607)$, pedicled bilateral internal thoracic artery $(\mathrm{n}=459)$, skeletonized single internal thoracic artery $(\mathrm{n}=512)$, and skeletonized bilateral internal thoracic artery $(\mathrm{n}=478)$. Propensity scores weighting was used to estimate the impact of the harvesting technique on sternal wound complications.
\end{abstract}

Results: A total of 219 of 2056 patients (10.6\%) experienced a sternal wound complication within 1 year from the index operation. Of those, only 25 patients $(1.2 \%)$ required sternal wound reconstruction. Pedicled bilateral internal thoracic artery (odds ratio [OR], 1.80; 95\% confidence interval [CI], 1.23-2.63) but not skeletonized bilateral internal thoracic artery (OR, 1.00; 95\% CI, 0.65-1.53) or skeletonized single internal thoracic artery (OR, 0.89; $95 \% \mathrm{CI}, 0.57-1.38)$ was associated with a significantly increased risk of any sternal wound complications compared with pedicled single internal thoracic artery.

Conclusions: The present Arterial Revascularization Trial substudy suggests that, with a skeletonization technique, the risk of sternal wound complication with bilateral internal thoracic artery grafting is similar to that after standard pedicled single internal thoracic artery harvesting, whereas skeletonized single internal thoracic artery harvesting did not add any further benefit when compared with pedicled single internal thoracic artery harvesting. ( $\mathrm{J}$ Thorac Cardiovasc Surg 2016;152:270-6)

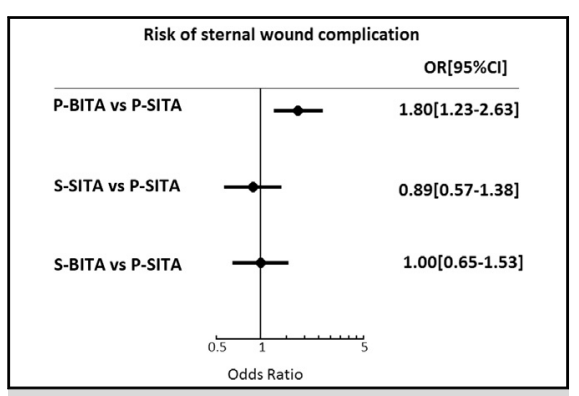

Forest plot for treatment effect estimates on sternal wound complication.

\section{Central Message}

In the ART, the risk of sternal wound complication with skeletonized BITAs was comparable to that after single pedicled harvesting.

\section{Perspective}

By using a skeletonized harvesting technique, the risk of sternal wound complication with BITA grafting is at a similar level to that after standard pedicled SITA harvesting even in patients at higher risk, such as insulin-dependent diabetic individuals, women, and those with increased BMI.

See Editorial Commentary page 277.

\section{$2016,152.270-6)$}

(G0200390). U.B.'s contribution was supported by the National Institute for Health Research Bristol Cardiovascular Biomedical Research Unit.

Clinical trial registration: ISRCTN46552265

Received for publication Jan 1, 2016; revisions received March 2, 2016; accepted for publication March 11, 2016; available ahead of print April 23, 2016.

Address for reprints: Umberto Benedetto, MD, $\mathrm{PhD}$, Bristol Heart Institute, University of Bristol Level 7, Bristol Royal Infirmary, Upper Maudlin St, BS2 8HW (E-mail: Umberto.benedetto@bristol.ac.uk).

0022-5223/\$36.00

Copyright () 2016 by The American Association for Thoracic Surgery http://dx.doi.org/10.1016/j.jtcvs.2016.03.056 


$$
\begin{aligned}
& \text { Abbreviations and Acronyms } \\
& \begin{aligned}
\text { ART } & =\text { Arterial Revascularization Trial } \\
\text { BITA } & =\text { bilateral internal thoracic artery } \\
\text { BMI } & =\text { body mass index } \\
\text { CABG } & =\text { coronary artery bypass grafting } \\
\text { CI } & =\text { confidence interval } \\
\text { ITA } & \text { internal thoracic artery } \\
\text { OR } & =\text { odds ratio } \\
\text { P } & \text { pedicled } \\
\text { S } & =\text { skeletonized } \\
\text { SITA } & =\text { single internal thoracic artery }
\end{aligned}
\end{aligned}
$$

Scanning this QR code will take you to the article title page.

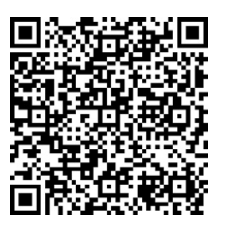

The long-term patency of conduits is one of the most important determinants of long-term outcomes in coronary artery bypass grafting (CABG). The left internal thoracic artery (ITA) is unanimously acknowledged as the best coronary conduit. ${ }^{1}$ Although the right ITA has identical function and patency rates as the left ITA and despite accumulation of evidence on long-term benefit by using bilateral ITAs (BITAs) over the past 20 years, ${ }^{2-4}$ the right ITA remains largely underused ${ }^{5}$ mainly because of concerns over the potential for sternal wound complications. ${ }^{6}$

There are 2 established techniques for harvesting the ITA: pedicled and skeletonized. Harvesting the ITA(s) in a pedicled fashion can potentially lead to significant sternal devascularization. ${ }^{7,8}$ As opposed to pedicled harvesting, minimization of tissue mobilization during skeletonized ITA harvesting has been shown to preserve substantial collateral flow to the sternum by sparing some of the sternal and intercostal branches that arise from the ITA as a common trunk. ${ }^{7,8}$ This finding may have potential clinical significance with respect to reducing the risk of sternal wound complications by improving wound healing and, in particular, when both left and right ITAs are used. ${ }^{9}$

However, the magnitude of the potential clinical benefit from skeletonized over pedicled ITA harvesting on sternal wound complications still remains to be determined. ${ }^{10,11}$ Moreover, skeletonized ITA harvesting is a more technically demanding and time-consuming technique, and concerns remain over a perceived increased risk of injury to the ITAs during skeletonization that may affect early outcomes. ${ }^{12}$ Consequently, in the absence of a general consensus, pedicled ITA harvesting remains the generally preferred approach worldwide.
The Arterial Revascularization Trial (ART) is a randomized comparison of BITA versus single ITA (SITA) grafting in CABG surgery ${ }^{13}$ and is one of the largest studies of contemporary $\mathrm{CABG}$ with a high proportion of patients undergoing skeletonized ITA harvesting. We studied the impact of ITA harvesting strategy on sternal wound complication by conducting an analysis of data collected prospectively in the ART.

\section{MATERIALS AND METHODS}

This research adheres to the principles set forth in the Declaration of Helsinki (http://www.wma.net/en/30publications/10policies/b3/index. html). The ART has been approved by the institutional review board of all participating centers, and informed consent was obtained from each participant. The protocol for the ART has been published. ${ }^{14}$ Briefly, the ART is a 2-arm, randomized multicenter trial conducted in 28 hospitals in 7 countries, with patients being randomized equally to SITA or BITA grafts. Eligible patients were those with multivessel coronary artery disease (including urgent patients but not evolving myocardial infarction) undergoing $\mathrm{CABG}$, whereas those requiring single grafts or redo $\mathrm{CABG}$ were excluded. Only surgeons with experience of 50 or more BITA operations were able to participate in the trial; standard methods for anesthesia and myocardial protection were used according to local practice. For the purpose of the present analysis, patients were classified according to the "as-treated" principle in the following groups: pedicled SITA (P-SITA), skeletonized SITA (S-SITA), pedicled BITA (P-BITA), and skeletonized BITA (S-BITA). The ITA harvesting technique was based on the surgeon's preference. This information was not recorded from the outset of the trial. Thus, only 2056 of 3102 patients were included in the analyses.

\section{Outcomes Definition}

The primary end point for these analyses was the incidence of any sternal wound complication within 1 year after the index procedure, which included a broad definition ranging from superficial sternal wound discharge to sternal wound reconstruction. We also investigated the impact of ITA harvesting strategy on the incidence of severe sternal wound complications, defined as sternal wound infection requiring antibiotics or sternal wound reconstruction. Adverse events including sternal wound complications were adjudicated blind by a member of the Clinical Event Review Committee.

\section{Statistical Analysis}

For baseline characteristics, variables are summarized as mean for continuous variables and percentage for categoric variables. The chisquare test was used to test unadjusted association between treatment variable and outcomes. Multiple imputation $(\mathrm{m}=3)$ was used to address missing data (165 patients). Rubin's method ${ }^{15}$ was used to combine results from each of $m$ imputed data sets.

Inverse probability of treatment weighting for modeling causal effects was used for multiple treatments comparison. ${ }^{16}$ One of the advantages of this technique over standard pairwise propensity matching is the possibility of simultaneous comparisons between multiple treatments. Moreover, all the individuals in the study can be used for the outcomes evaluation, whereas a large number of subjects may not be used in a propensity matching. A generalized boosted model was implemented to estimate multinomial propensity scores adjusting for 14 pretreatment covariates, and the propensity score was assumed as the probability that an individual with pretreatment characteristics $\mathrm{X}$ receives treatment $\mathrm{t}$ (twang $\mathrm{R}$ package). The average treatment effect on the population was used to answer the question of how, on average, the outcome of interest would change if everyone in the population of interest had been assigned to a particular treatment relative to if they had all received another single treatment. To estimate the average treatment effect on the population, we gave treated 
TABLE 1. Distribution of pretreatment variables (as mean or percentage) before (unweighted) and after (weighted) propensity score

\begin{tabular}{|c|c|c|c|c|c|c|c|c|c|c|c|c|}
\hline & \multicolumn{5}{|c|}{ Unweighted } & \multirow[b]{2}{*}{$P$ value } & \multicolumn{5}{|c|}{ Weighted } & \multirow[b]{2}{*}{$P$ value } \\
\hline & $\begin{array}{l}\text { P-SITA } \\
\mathbf{n}=607\end{array}$ & $\begin{array}{l}\text { S-SITA } \\
\mathrm{n}=\mathbf{5 1 2}\end{array}$ & $\begin{array}{l}\text { P-BITA } \\
n=459\end{array}$ & $\begin{array}{l}\text { S-BITA } \\
n=478\end{array}$ & ASMD & & $\begin{array}{c}\text { P-SITA } \\
\text { ESS }=\mathbf{5 5 0}\end{array}$ & $\begin{array}{c}\text { S-SITA } \\
\text { ESS }=454\end{array}$ & $\begin{array}{c}\text { P-BITA } \\
\text { ESS }=429\end{array}$ & $\begin{array}{c}\text { S-BITA } \\
\text { ESS }=430\end{array}$ & ASMD & \\
\hline Age, y $(\mathrm{SD}, 9)$ & 64 & 65 & 63 & 64 & 0.23 & $<.001$ & 64 & 64 & 64 & 64 & 0.06 & .36 \\
\hline Female & $11 \%$ & $19 \%$ & $12 \%$ & $14 \%$ & 0.22 & $<.001$ & $12 \%$ & $14 \%$ & $13 \%$ & $12 \%$ & 0.05 & .36 \\
\hline $\mathrm{BMI}(\mathrm{SD}, 4)$ & 28.29 & 28.17 & 28.30 & 28.38 & 0.05 & .44 & 28.24 & 28.28 & 28.31 & 28.24 & 0.02 & .77 \\
\hline $\begin{array}{l}\text { Creatinine, } \\
\quad \mathrm{mmol} / \mathrm{L}(\mathrm{SD}, 22)\end{array}$ & 97.91 & 100.00 & 98.23 & 98.30 & 0.09 & .13 & 97.83 & 98.97 & 98.36 & 98.43 & 0.05 & .37 \\
\hline NYHA III/IV & $26 \%$ & $19 \%$ & $28 \%$ & $22 \%$ & 0.20 & $<.001$ & $24 \%$ & $22 \%$ & $24 \%$ & $21 \%$ & 0.06 & .37 \\
\hline Diabetes orally treated & $19 \%$ & $19 \%$ & $19 \%$ & $19 \%$ & 0.02 & .70 & $18 \%$ & $19 \%$ & $19 \%$ & $19 \%$ & 0.02 & .73 \\
\hline Diabetes on insulin & $5 \%$ & $6 \%$ & $3 \%$ & $8 \%$ & 0.21 & $<.001$ & $5 \%$ & $6 \%$ & $3 \%$ & $6 \%$ & 0.13 & .02 \\
\hline Smoker & $12 \%$ & $13 \%$ & $14 \%$ & $16 \%$ & 0.10 & .10 & $13 \%$ & $13 \%$ & $13 \%$ & $14 \%$ & 0.03 & .65 \\
\hline COPD & $7 \%$ & $6 \%$ & $9 \%$ & $6 \%$ & 0.13 & .05 & $7 \%$ & $7 \%$ & $7 \%$ & $6 \%$ & 0.04 & .51 \\
\hline PVD & $9 \%$ & $8 \%$ & $7 \%$ & $7 \%$ & 0.07 & .27 & $7 \%$ & $8 \%$ & $7 \%$ & $8 \%$ & 0.04 & .61 \\
\hline Prior stroke & $3 \%$ & $4 \%$ & $2 \%$ & $3 \%$ & 0.09 & .16 & $3 \%$ & $3 \%$ & $2 \%$ & $3 \%$ & 0.09 & .10 \\
\hline Prior MI & $42 \%$ & $44 \%$ & $39 \%$ & $35 \%$ & 0.19 & $<.001$ & $41 \%$ & $41 \%$ & $42 \%$ & $39 \%$ & 0.06 & .38 \\
\hline LVEF $<0.50$ & $28 \%$ & $26 \%$ & $23 \%$ & $21 \%$ & 0.16 & .01 & $26 \%$ & $25 \%$ & $25 \%$ & $23 \%$ & 0.06 & .39 \\
\hline Caucasian & $91 \%$ & $92 \%$ & $88 \%$ & $92 \%$ & 0.15 & .02 & $91 \%$ & $92 \%$ & $91 \%$ & $93 \%$ & 0.07 & .28 \\
\hline On pump & $56 \%$ & $42 \%$ & $52 \%$ & $39 \%$ & 0.35 & .00 & $49 \%$ & $46 \%$ & $48 \%$ & $46 \%$ & 0.07 & .29 \\
\hline
\end{tabular}

P-SITA, Pedicled single internal thoracic artery; S-SITA, skeletonized single internal thoracic artery; $P$-BITA, pedicled bilateral internal thoracic artery; $S$-BITA, skeletonized bilateral internal thoracic artery; $A S M D$, absolute standardized mean difference; ESS, effective sample size; $S D$, standard deviation; $B M I$, body mass index; $N Y H A$, New York Heart Association; $C O P D$, chronic obstructive pulmonary disease; $P V D$, peripheral vascular disease; $M I$, myocardial infarction; $L V E F$, left ventricular ejection fraction.

patients weight $\mathrm{w}_{\mathrm{i}}=1 /\left(1-\mathrm{p}\left(\mathrm{x}_{\mathrm{i}}\right)\right)$, where $\mathrm{p}(\mathrm{xi})$ is the propensity score, and reference patients $\mathrm{w}_{\mathrm{i}}=1 / \mathrm{p}\left(\mathrm{x}_{\mathrm{i}}\right)$. P-SITA was considered as the reference group in all comparisons. The absolute standardized mean difference was used as a balance metric to summarize the difference between 2 univariate distributions of a single pretreatment variable. A value of 0.20 or greater $(20 \%)$ was considered as an indicator of imbalance. ${ }^{17}$ Effective sample size was calculated to account for the potential loss in precision from weighting. ${ }^{16}$ We then estimated the treatment effect estimates with a weighted regression model that contained only a treatment indicator. In addition, a combination of propensity score weighting and covariate adjustment (double robust) was used to correct the effect of ITA harvesting technique for residual imbalance and to estimate the effect size of other covariates. Last, we estimated the treatment effect within subgroups according to the presence of diabetes on insulin, gender, and body mass index (BMI) 30 or greater. $\mathrm{R}$ version 3.1.2 (October 31, 2014) was used for all statistical analysis.

\section{RESULTS}

\section{Study Population}

Among 2056 patients included in the present analysis, 1022 and 1034 were initially allocated to BITA and SITA, respectively. The crossover rate from BITA to SITA was $115 / 1022(11.2 \%)$ and from SITA to BITA was 30/1034 $(2.9 \%)$. Finally, 937 and 1119 patients received BITA and SITA, respectively. ITA harvesting groups compared were 607 P-SITA, 459 P-BITA, 512 S-SITA, and 478 S-BITA. The second ITA was initially attempted to be harvested but not used in 15 BITA to SITA crossovers. Of those, 5 were skeletonized and 10 were pedicled. Reasons for the second ITA not to be used were evidence of injury during harvesting ( $\mathrm{n}=4$, all pedicled), unsatisfactory flow $(\mathrm{n}=5,3$ skeletonized, 2 pedicled), or unsatisfactory length or size ( $n=6,2$ skeletonized, 4 pedicled). Overall, the rate of injured/unsatisfactory second ITA was $5 / 483(1.0 \%)$ by using a skeletonized technique and $10(2.1 \%)$ by using a pedicled technique $(P=.22)$. Among those 15 cases, only 1 patient who underwent pedicled harvesting experienced a sternal wound complication.

\section{Distribution of Pretreatment Variables Among Internal Thoracic Artery Harvesting Technique Groups}

Table 1 summarizes the distribution of pretreatment variables. Although the 4 groups were comparable for most of the pretreatment variables, insulin-dependent diabetes was more common in patients receiving S-BITA than in patients receiving P-BITA. In addition, more women received S-SITA or S-BITA. Finally, off-pump surgery was more frequently performed in the S-SITA and S-BITA groups compared with the pedicled groups.

After multinomial propensity score estimation, a balance check showed that the groups were sufficiently similar (absolute standardized mean differences $<0.20$ ) to support causal estimation of the treatment effects, although subjects receiving P-BITA continued to have a slightly lower prevalence of diabetes on insulin.

\section{Incidence of Sternal Wound Complications}

A total of 219 of 2056 patients $(10.7 \%)$ experienced a sternal wound complication within 1 year from the index operation. Of those, $75(3.6 \%)$ had severe sternal wound complications, including 50 patients $(2.4 \%)$ with sternal wound infection requiring antibiotic therapy but not reconstruction and 25 patients $(1.2 \%)$ who required sternal wound reconstruction. Most sternal wound complications 

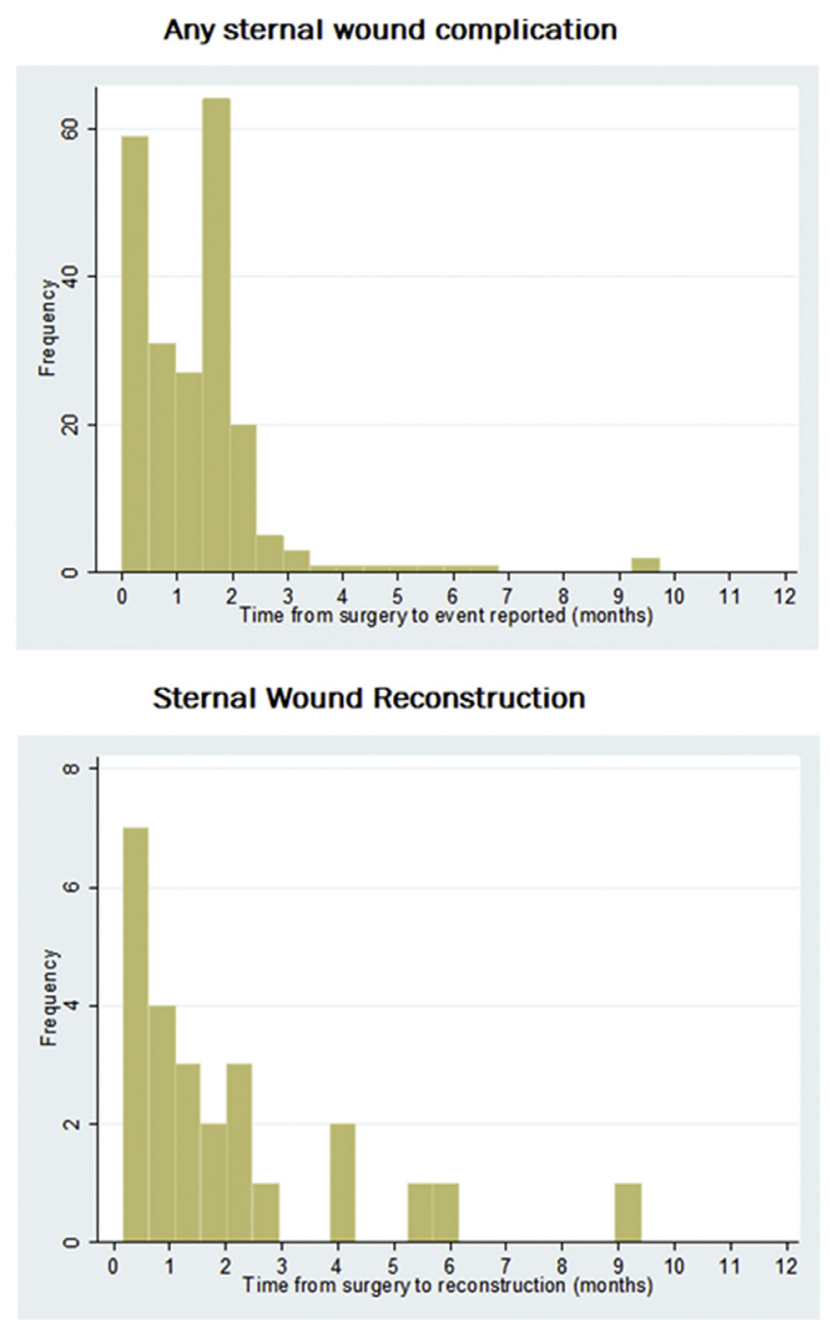

FIGURE 1. Time from index operation to any and severe sternal wound complication.

including those requiring reconstruction occurred during the first 3 months (Figure 1).

\section{Effect of Harvesting Technique on Sternal Wound Complication}

Table 2 and Figure 2 show the incidence of any sternal wound complications according to ITA harvesting groups. Patients receiving P-BITA had a higher incidence of any sternal wound complication compared with the other groups. There were too few severe wound complications to detect differences among the treatment groups. Table 3 summarizes the effect of ITA harvesting technique on the incidence of any sternal wound complications. Propensity score-weighted analysis showed that P-BITA but not S-BITA was associated with a significantly increased risk ( $\sim 2$ times) of any sternal wound complications when compared with P-SITA. On the other hand, S-SITA did not provide any benefit on the incidence of any sternal wound complication when compared with P-SITA (Figure 3). When the analysis was restricted to severe sternal wound complications only, we were unable to demonstrate any significant impact of P-BITA (odds ratio [OR], $1.60 ; 95 \%$ confidence interval [CI], 0.85-3.00), S-BITA (OR, 1.15; 95\% CI, 0.58-2.28), and S-SITA (OR, 0.97; 95\% CI, 0.45-2.07) when compared with P-SITA.

\section{Subgroup Analysis}

Subgroup analysis (Table 3) suggested that the detrimental effect of P-BITA on the incidence of any sternal wound complication might be exaggerated in the presence of diabetes on insulin (OR, 4.05; 95\% CI, 0.86-19.21), although this analysis was largely underpowered because of the small number of patients taking insulin $(n=118)$. Of note, P-BITA remained significantly associated with a higher risk of any sternal wound complication in nondiabetic patients (OR, 1.84; 95\% CI, 1.18-2.85). Moreover, P-BITA significantly increased the risk of any sternal wound complication in both obese and nonobese patients.

In the situation of a SITA, S-SITA did not add any significant benefit in terms of sternal wound complication when compared with P-SITA also among high-risk subgroups.

\section{Independent Risk Factors for Sternal Wound Complication}

In a double robust analysis (Tables 4 and 5), P-BITA but not S-BITA remained independently associated with an increased risk of any sternal wound complication. Insulindependent diabetes, female gender, and higher BMI were independent risk factors for any and severe sternal wound complications.

\section{Mortality Within 30 Days and at 1 Year}

There were $31(1.5 \%)$ deaths within 30 days and 55 $(2.6 \%)$ deaths by 1 -year follow-up. Mortality at 30 days and 1 year was comparable among ITA harvesting groups (Table 2). The 30-day mortality among patients with and without sternal wound reconstruction was $0 / 25(0 \%)$ and $31 / 2031(1.5 \%)$. At 1 year, total deaths among patients with and without sternal wound reconstruction were $3 / 25$ $(12 \%)$ and $52 / 2031(2.7 \%)$, respectively.

\section{DISCUSSION}

Despite increasing evidence from observational studies of the long-term survival benefit of a second ITA, ${ }^{2,3}$ it remains largely underused, being used in $4.1 \%$ of CABG procedures in the United States ${ }^{5}$ and approximately $10 \%$ in the United Kingdom and Australia. ${ }^{18}$ Concern about sternal wound complication is one of the main reasons limiting the use of more than 1 ITA, because a severe sternal wound complication dramatically increases in-hospital mortality and the expense of hospital stay. ${ }^{6}$ 
TABLE 2. Outcomes among treatment groups

\begin{tabular}{|c|c|c|c|c|c|c|}
\hline & \multirow[b]{2}{*}{$\begin{array}{l}\text { All SWC } \\
(\mathbf{n}=\mathbf{2 1 9})\end{array}$} & \multicolumn{3}{|c|}{$\begin{array}{c}\text { Severe SWC } \\
(n=150)\end{array}$} & \multirow[b]{2}{*}{$\begin{array}{l}\text { 30-d mortality } \\
\quad(n=31)\end{array}$} & \multirow[b]{2}{*}{$\begin{array}{l}\text { 1-y mortality } \\
\quad(n=55)\end{array}$} \\
\hline & & All $(n=75)$ & $\begin{array}{c}\text { SWC requiring } \\
\text { antibiotics }(n=50)\end{array}$ & $\begin{array}{c}\text { Sternal wound } \\
\text { reconstruction }(n=25)\end{array}$ & & \\
\hline P-SITA $(\mathrm{n}=607)$ & $58(9.5 \%)$ & $20(3.3 \%)$ & $14(2.3 \%)$ & $6(1.0 \%)$ & $8(1.3 \%)$ & $13(2.1 \%)$ \\
\hline S-SITA $(n=512)$ & $41(8.0 \%)$ & $14(2.7 \%)$ & $12(2.3 \%)$ & $2(0.4 \%)$ & $8(1.6 \%)$ & $15(2.9 \%)$ \\
\hline P-BITA $(\mathrm{n}=459)$ & $74(16.1 \%)$ & $24(5.2 \%)$ & $17(3.7 \%)$ & $7(1.5 \%)$ & $7(1.5 \%)$ & $12(2.6 \%)$ \\
\hline S-BITA $(n=478)$ & $46(9.6 \%)$ & $17(3.7 \%)$ & $7(1.5 \%)$ & $10(2.1 \%)$ & $8(1.7 \%)$ & $15(3.1 \%)$ \\
\hline \multicolumn{7}{|c|}{ Chi-square tests P P-SITA as reference } \\
\hline S-SITA & 0.39 & 0.60 & 1 & 0.30 & 0.80 & 0.44 \\
\hline P-BITA & 0.0014 & 0.12 & 0.19 & 0.57 & 0.79 & 0.68 \\
\hline S-BITA & 1 & 0.86 & 0.37 & 0.20 & 0.62 & 0.33 \\
\hline
\end{tabular}

$\overline{S W C}$, Sternal wound complication; $P$-SITA, pedicled single internal thoracic artery; S-SITA, skeletonized single internal thoracic artery; $P$-BITA, pedicled bilateral internal thoracic artery; S-BITA, skeletonized bilateral internal thoracic artery.

The present post hoc analysis of the ART demonstrates that in the modern era of CABG surgery, sternal wound complications still affect approximately $10 \%$ of patients. In particular, severe sternal wound infection requiring antibiotic therapy or sternal wound reconstruction still affects approximately $2 \%$ and $1 \%$ of the surgical population, respectively. The anticipated impact of sternal wound complication on resource consumption and patient outcomes represents an important consideration in the use of BITA grafting and an argument in favor of skeletonized ITA over pedicled ITA harvesting.

The main finding of the present analysis is that BITA harvesting can be safely performed using the skeletonized technique without increasing the risk of sternal wound complications when compared with the standard approach using a P-SITA. Furthermore, S-BITA harvesting does not seem to significantly increase the risk even in higher-risk groups, such as diabetic patients taking insulin, women, and obese patients (BMI $\geq 30$ ) who have been shown to benefit from the use of BITA grafting. ${ }^{19-21}$ On the other hand, P-BITA was associated with an approximately 2-fold increased

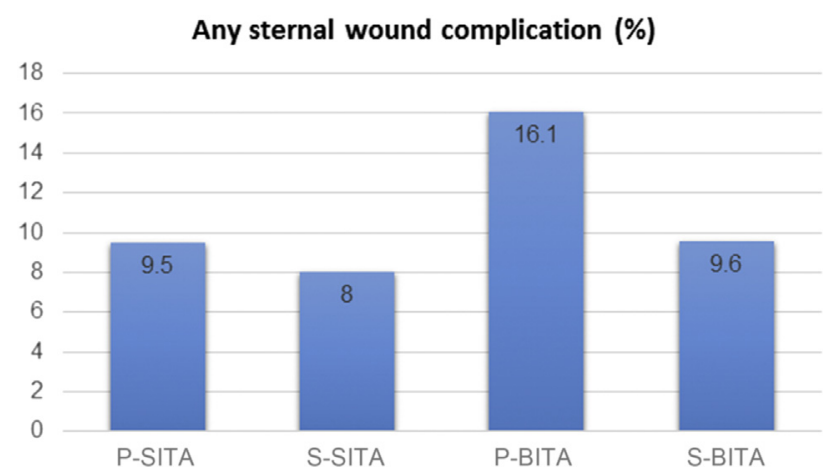

FIGURE 2. Incidence of any sternal wound complication according to ITA harvesting strategies. P-SITA, Pedicled single internal thoracic artery; S-SITA, skeletonized single internal thoracic artery; $P$-BITA, pedicled bilateral internal thoracic artery; $S$-BITA, skeletonized bilateral internal thoracic artery. risk of any sternal wound complication. The detrimental effect of P-BITA harvesting on sternal wound complication was relevant not only in high-risk cases, such as those who were obese or had insulin-dependent diabetes, but also in the lowest-risk CABG population who were not diabetic or obese, whereas S-BITA harvesting did not significantly increase the risk of sternal wound complications.

On the other hand, in the context of a SITA graft, there was no evidence of the superiority of S-SITA harvesting over P-SITA harvesting in reducing the risk of sternal wound complications.

Skeletonized harvesting has been proposed to minimize the risk of sternal wound complication by preserving sternal perfusion especially in the context of BITA use. ${ }^{6}$ Kamiya and colleagues ${ }^{7}$ showed better oxygen saturation and blood flow in the microcirculation of sternal tissue when using skeletonized rather than pedicled ITA. Likewise, Boodhwani and colleagues, ${ }^{8}$ using radionuclear perfusion scanning, demonstrated that sternal perfusion was greater after skeletonized rather than pedicled harvesting.

However, whether skeletonized ITA harvesting should be considered the standard approach with BITA grafting and whether this approach also provides a significant benefit in SITA grafting still need to be determined. The potential clinical superiority of skeletonized over pedicled harvesting on sternal wound complications has been addressed in only a few studies with conflicting results reported. ${ }^{10,11}$ Studies published to date are remarkably underpowered to detect any clinical benefit on low-rate events, such as sternal wound complications. ${ }^{11}$ Moreover, skeletonized harvesting is more technically demanding and time-consuming, and, in the absence of general consensus, pedicled harvesting still remains the preferred approach worldwide.

The ART is one of the largest studies of contemporary CABG with a high proportion of patients undergoing skeletonized ITA harvesting. ${ }^{13}$ To our knowledge, the present study is the largest analysis on the impact of ITA harvesting performed to date. We found that skeletonization 
TABLE 3. Propensity score weighted effect (odds ratio; $95 \%$ confidence interval) of internal thoracic artery harvesting on sternal wound complication

\begin{tabular}{|c|c|c|c|c|c|c|c|c|}
\hline $\begin{array}{c}\text { Comparison } \\
\text { P-SITA as } \\
\text { reference }\end{array}$ & $\begin{array}{c}\text { Overall } \\
N=2056\end{array}$ & $\begin{array}{c}\text { Diabetes } \\
\text { on insulin } \\
\mathbf{N}=\mathbf{1 1 8}\end{array}$ & $\begin{array}{c}\text { Diabetes } \\
\text { orally } \\
\text { treated } \\
\mathbf{N}=\mathbf{3 8 6}\end{array}$ & $\begin{array}{c}\text { Not diabetic } \\
\mathbf{N}=1552\end{array}$ & $\begin{array}{c}\text { Female } \\
\mathbf{N}=\mathbf{2 8 3}\end{array}$ & $\begin{array}{c}\text { Male } \\
N=1773\end{array}$ & $\begin{array}{c}\text { BMI } \geq \mathbf{3 0} \\
\mathbf{N}=\mathbf{6 3 1}\end{array}$ & $\begin{array}{l}\text { BMI }<30 \\
\mathbf{N}=\mathbf{1 4 2 5}\end{array}$ \\
\hline P-BITA & $1.80(1.23-2.63)$ & $4.05(0.86-19.21)$ & $1.41(0.58-3.45)$ & 1.84 & $.08(0.41-2.83)$ & $1.96(1.30-2.98)$ & $2.07(1.09-3.90)$ & $1.67(1.03-2.68)$ \\
\hline S-SITA & $0.89(0.57-1.38)$ & $1.35(0.29-6.15)$ & $1.25(0.49-3.19)$ & 0.75 & $0.72(0.27-1.90)$ & $0.91(0.55-1.51)$ & $1.46(0.73-2.90)$ & $1.09(0.65-1.83)$ \\
\hline S-BITA & $1.00(0.65-1.53)$ & $1.92(0.48-7.73)$ & $1.54(0.64-3.73)$ & 0.78 & $1.59(0.65-3.91)$ & $0.86(0.52-1.42)$ & $0.83(0.39-1.80)$ & $0.59(0.32-1.09)$ \\
\hline
\end{tabular}

Bold values signify $P<.05$. $P$-SITA, Pedicled single internal thoracic artery; BMI, body mass index; $P$-BITA, pedicled bilateral internal thoracic artery; $S$-BITA, skeletonized bilateral internal thoracic artery; $S$-SITA, skeletonized single internal thoracic artery.

while performing BITA was safe because it did not increase the risk of damage to the harvested ITA. In fact, the rate of an injured/unsatisfactory second ITA was $1.0 \%$ by using a skeletonized technique and $2.1 \%$ by using a pedicled technique, thus supporting previous reports. ${ }^{22}$ Moreover, the mortality rate at 30 days and 1 year was comparable between the 2 techniques. With regard to sternal wound complications, S-BITA harvesting did not increase its risk when compared with P-SITA, and subgroup analysis suggested a protective effect from S-BITA among highrisk subjects. On the other hand, P-BITA grafts seemed to increase the risk of sternal wound complications among low-risk subgroups (ie, not obese or taking insulin). We also found no evidence that S-SITA harvesting added any protective effect when compared with a P-SITA.

\section{Study Limitations}

Despite propensity score adjustment, the present analysis was unable to address hidden biases because of unobserved differences between treated and control patients before treatment. The present study was underpowered to detect

\section{Risk of sternal wound complication}

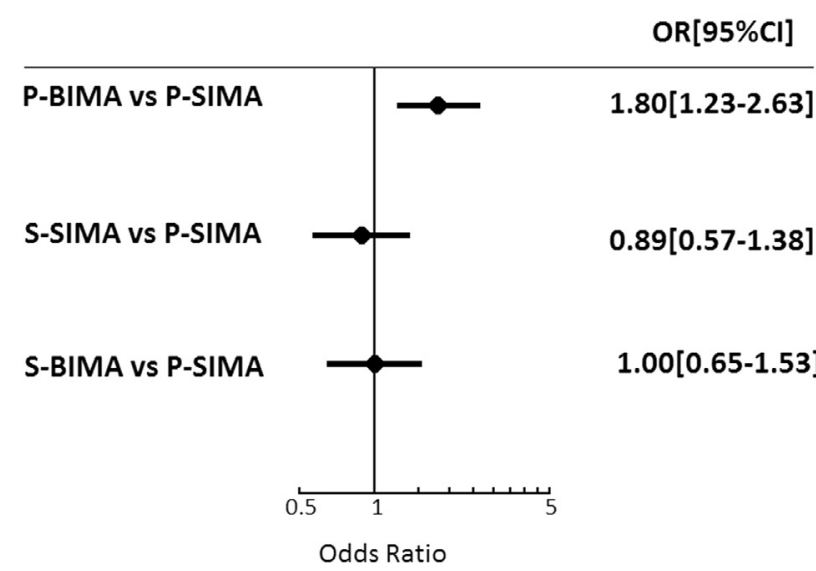

FIGURE 3. Forest plot for treatment effect estimates on sternal wound complication. P-SIMA, Pedicled single internal thoracic artery; S-SIMA, skeletonized single internal thoracic artery; $P$-BIMA, pedicled bilateral internal thoracic artery; $S$-BIMA, skeletonized bilateral internal thoracic artery; $O R$, odds ratio; $C I$, confidence interval. differences in severe sternal wound complications among groups, and most of the sternal complications were clinically less relevant. Fortunately, the low incidence of severe sternal wound complications would have required a larger number of patients for analysis. Nevertheless, the difference in the rate of severe wound problems between the 2 groups supports the intrinsic benefit of the skeletonized technique of artery harvesting in terms of severe sternal wound complications. Sparing of the communicating bifurcation of the ITA to the chest wall and preservation of pericardiacophrenic artery branch has been reported to minimize the risk of sternal wound complication in patients receiving P-BITA. ${ }^{23}$ In the present study, we could not confirm this hypothesis because data on technical aspects of harvesting technique were not reported.

TABLE 4. Results of double robust propensity score-weighted analysis on the incidence of any sternal wound complication

\begin{tabular}{lcccc}
\hline & OR & $\mathbf{9 5} \%$ CI LL & $\mathbf{9 5} \%$ CI UL & $\boldsymbol{P}$ value \\
\hline P-BITA vs P-SITA & 1.85 & 1.25 & 2.74 & .002 \\
S-SITA vs P-SITA & 0.98 & 0.64 & 1.52 & .94 \\
S-BITA vs P-SITA & 0.87 & 0.55 & 1.36 & .53 \\
Age* & 1.00 & 0.99 & 1.02 & .77 \\
Female & 1.58 & 1.07 & 2.34 & .02 \\
BMI* & 1.08 & 1.04 & 1.13 & $<.001$ \\
Creatinine* & 0.99 & 0.98 & 1.00 & .01 \\
NYHA III-IV & 1.01 & 0.70 & 1.45 & .96 \\
Diabetes orally treated & 1.20 & 0.82 & 1.74 & .34 \\
Diabetes on insulin & 2.17 & 1.29 & 3.66 & .003 \\
Smoking & 1.27 & 0.83 & 1.95 & .27 \\
COPD & 1.23 & 0.70 & 2.18 & .47 \\
PVD & 0.81 & 0.44 & 1.48 & .49 \\
Prior stroke & 1.67 & 0.80 & 3.50 & .17 \\
Prior MI & 0.94 & 0.68 & 1.30 & .70 \\
LVEF $<0.50$ & 1.02 & 0.71 & 1.46 & .91 \\
Caucasian & 1.09 & 0.79 & 1.50 & .59 \\
\hline$O R, O d s$
\end{tabular}

OR, Odds ratio; $C I$, confidence interval; $L L$, lower limit; $U L$, upper limit; $P$-BITA pedicled bilateral internal thoracic artery; $P$-SITA, pedicled single internal thoracic artery; S-SITA, skeletonized single internal thoracic artery; S-BITA, skeletonized bilateral internal thoracic artery; $B M I$, body mass index; $N Y H A$, New York Heart Association; $C O P D$, chronic obstructive pulmonary disease; $P V D$, peripheral vascular disease; $M I$, myocardial infarction; $L V E F$, left ventricular ejection fraction *Used as continuous variable. 
TABLE 5. Results of double robust propensity score-weighted analysis on the incidence of severe sternal wound complication

\begin{tabular}{lcccc}
\hline & OR & $\mathbf{9 5} \%$ CI LL & 95\% CI UL & $\boldsymbol{P}$ value \\
\hline P-BITA vs P-SITA & 1.61 & 0.85 & 3.07 & .15 \\
S-SITA vs P-SITA & 1.14 & 0.56 & 2.31 & .71 \\
S-BITA vs P-SITA & 0.92 & 0.43 & 1.98 & .82 \\
Age* & 1.00 & 0.97 & 1.03 & .79 \\
Female & 2.48 & 1.38 & 4.45 & .002 \\
BMI* & 1.11 & 1.04 & 1.18 & .001 \\
Creatinine* & 1.00 & 0.99 & 1.01 & .76 \\
NYHA III-IV & 0.83 & 0.42 & 1.61 & .57 \\
Diabetes orally treated & 1.78 & 1.00 & 3.16 & .049 \\
Diabetes on insulin & 2.72 & 1.25 & 5.92 & .01 \\
Smoking & 1.72 & 0.88 & 3.35 & .11 \\
COPD & 2.08 & 0.97 & 4.46 & .06 \\
PVD & 0.53 & 0.17 & 1.66 & .27 \\
Prior stroke & 1.74 & 0.62 & 4.90 & .29 \\
Prior MI & 0.92 & 0.54 & 1.59 & .77 \\
LVEF $<0.50$ & 1.03 & 0.56 & 1.87 & .93 \\
Caucasian & 1.26 & 0.73 & 2.18 & .40 \\
\hline
\end{tabular}

$O R$, Odds ratio; $C I$, confidence interval; $L L$, lower limit; $U L$, upper limit; $P$-BITA, pedicled bilateral internal thoracic artery; $P$-SITA, pedicled single internal thoracic artery; S-SITA, skeletonized single internal thoracic artery; S-BITA, skeletonized bilateral internal thoracic artery; $B M I$, body mass index; $N Y H A$, New York Heart Association; COPD, chronic obstructive pulmonary disease; $P V D$, peripheral vascular disease; $M I$, myocardial infarction; $L V E F$, left ventricular ejection fraction. *Used as continuous variable.

\section{CONCLUSIONS}

The present ART substudy suggests that with a skeletonization technique, the risk of sternal wound complication with BITA grafting is at a similar level to that after standard P-SITA harvesting, whereas S-SITA harvesting did not add any further benefit when compared with P-SITA harvesting. S-BITA harvesting seems to provide a protective effect also in those at higher risk, such as insulin-dependent diabetic individuals, women, and those with increased BMI.

\section{Conflict of Interest Statement}

Authors have nothing to disclose with regard to commercial support.

\section{References}

1. Loop FD, Lytle BW, Cosgrove DM, Stewart RW, Goormastic M, Williams GW, et al. Influence of the internal-mammary-artery graft on 10-year survival and other cardiac events. N Engl J Med. 1986;314:1-6.

2. Taggart DP, D'Amico R, Altman DG. Effect of arterial revascularisation on survival: a systematic review of studies comparing bilateral and single internal mammary arteries. Lancet. 2001;358:870-5.

3. Yi G, Shine B, Rehman SM, Altman DG, Taggart DP. Effect of bilateral internal mammary artery grafts on long-term survival: a meta-analysis approach. $\mathrm{Circu}$ lation. 2014;130:539-45.

4. Benedetto U, Raja SG, Albanese A, Amrani M, Biondi-Zoccai G, Frati G. Searching for the second best graft for coronary artery bypass surgery: a network meta-analysis of randomized controlled trials. Eur J Cardiothorac Surg. 2015; 47:59-65.
5. Tabata M, Grab JD, Khalpey Z, Edwards FH, O'Brien SM, Cohn LH, et al. Prevalence and variability of internal mammary artery graft use in contemporary multivessel coronary artery bypass graft surgery. Circulation. 2009;120:935-40.

6. Catarino PA, Black E, Taggart DP. Why do UK cardiac surgeons not perform their first choice operation for coronary artery bypass graft? Heart. 2002;88: 643-4.

7. Kamiya H, Akhyari P, Martens A, Karck M, Haverich A, Lichtenberg A. Sternal microcirculation after skeletonized versus pedicled harvesting of the internal thoracic artery: a randomized study. J Thorac Cardiovasc Surg. 2008; 135:32-7.

8. Boodhwani M, Lam BK, Nathan HJ, Mesana TG, Ruel M, Zeng W, et al. Skeletonized internal thoracic artery harvest reduces pain and dysesthesia and improves sternal perfusion after coronary artery bypass surgery: a randomized, double blind, within-patient comparison. Circulation. 2006;114:766-73.

9. Sá MP, Cavalcanti PE, de Andrade Costa Santos HJ, Soares AF, Albuquerque Miranda RG, Araújo ML, et al. Skeletonized versus pedicled bilateral internal mammary artery grafting: outcomes and concerns analyzed through a metaanalytical approach. Int J Surg. 2015;16:146-52.

10. Sá MP, Ferraz PE, Escobar RR, Vasconcelos FP, Ferraz AA, Braile DM, et al. Skeletonized versus pedicled internal thoracic artery and risk of sternal wound infection after coronary bypass surgery: meta-analysis and meta-regression of 4817 patients. Interact Cardiovasc Thorac Surg. 2013;16:849-57.

11. Onorati F, Esposito A, Pezzo F, di Virgilio A, Mastroroberto P, Renzulli A. Hospital outcome analysis after different techniques of left internal mammary grafts harvesting. Ann Thorac Surg. 2007;84:1912-9.

12. Raja SG, Dreyfus GD. Internal thoracic artery: to skeletonize or not to skeletonize? Ann Thorac Surg. 2005;79:1805-11.

13. Taggart DP, Altman DG, Gray AM, Lees B, Nugara F, Yu LM, et al; ART Investigators. Randomized trial to compare bilateral vs. single internal mammary coronary artery bypass grafting: 1-year results of the Arterial Revascularisation Trial (ART). Eur Heart J. 2010;31:2470-81.

14. Taggart DP, Lees B, Gray A, Altman DG, Flather M, Channon K, ART Investigators. Protocol for the Arterial Revascularisation Trial (ART). A randomised trial to compare survival following bilateral versus single internal mammary grafting in coronary revascularisation. Trials. 2006;7:7.

15. Rubin DB. Multiple Imputation for Nonresponse in Surveys. New York: J Wiley \& Sons; 1987.

16. McCaffrey DF, Griffin BA, Almirall D, Slaughter ME, Ramchand R, Burgette LF. A tutorial on propensity score estimation for multiple treatments using generalized boosted models. Stat Med. 2013:32:3388-414.

17. Cohen J. Statistical Power Analysis for the Behavioral Sciences. 2nd ed. Hillsdale, NJ: Lawrence Erlbaum Associates Publishers; 1988.

18. Bridgewater B, Keogh B, on behalf of the Society for Cardiothoracic Surgery in Great Britain and Ireland. Sixth National Adult Cardiac Surgical Database Report 2008. Available at: http://www.scts.org/_userfiles/resources/SixthNACSD report2008withcovers.pdf. Accessed April 20, 2016.

19. Benedetto U, Montecalvo A, Kattach H, Amrani M, Raja SG, Harefield Cardiac Outcomes Research Group. Impact of the second internal thoracic artery on short- and long-term outcomes in obese patients: a propensity score matched analysis. J Thorac Cardiovasc Surg. 2015;149:841-7.

20. Cho KR, Kim JS, Choi JS, Kim KB. Serial angiographic follow-up of grafts one year and five years after coronary artery bypass surgery. Eur J Cardiothorac Surg. 2006;29:511-6.

21. Wee CC, Girotra S, Weinstein AR, Mittleman MA, Mukamal KJ. The relationship between obesity and atherosclerotic progression and prognosis among patients with coronary artery bypass grafts the effect of aggressive statin therapy. J Am Coll Cardiol. 2008;52:620-5.

22. Athanasiou T, Crossman MC, Asimakopoulos G, Cherian A, Weerasinghe A, Glenville, et al. Should the internal thoracic artery be skeletonized? Ann Thorac Surg. 2004; 77:2238-46.

23. Sajja LR, Mannam G, Dandu SB, Sompalli S. Reduction of sternal wound infections in diabetic patients undergoing off-pump coronary artery bypass surgery and using modified pedicle bilateral internal thoracic artery harvest technique. J Thorac Cardiovasc Surg. 2012;144:480-5.

Key Words: coronary artery bypass grafting, bilateral internal thoracic arteries, sternal wound infection 